\title{
Seeing the Invisible: Change of State Identity and Economic Interest in Turkish-Arab Relations, 2002-2012
}

\author{
Görünmeyeni Görmek: \\ Devlet Kimliğinin Dönüşümü ve Türk-Arap IIlişkilerinde \\ Ekonomik Çıkarlar, 2002-2012
}

\begin{abstract}
(iD) Abdullah Enes Tüzgen
ibn Haldun Üniversitesi, Türkiye

enes.tuzgen@ihu.edu.tr

Received: November 20, 2021

Accepted: January 24, 2022

Published: January 30, 2022

Abstract: Compared to previous decades, we observe a dramatic increase in international trade between Turkey and the Middle East between 2002 and 2012. Turkish exports to the Middle East and FDI from Arab countries to Turkey have increased 13 and 4.5 times, respectively. What explains such changes? I argue that the transformation in Turkish state identity resulted into a change in interest conceptualization. Since what the "Middle East" meant has changed with the new identity, previously "unseen" economic interests became visible.
\end{abstract}

Keywords: Turkish Foreign Policy, the Middle East, Constructivism, State Identity, Interest Conceptualization

Öz: Daha önceki on yıllara kıyasla, 2002-2012 yılları arasında Türkiye ile Ortadoğu ülkeleri arasındaki uluslararası ticarette yüksek oranda bir artış gözlemlenmektedir. Bu on yıllık dönemde, Türkiye'nin Ortadoğu ülkelerine ihracatı 13 kat, bu ülkelerden Türkiye'ye yönelik doğrudan yatırım ise 4,5 kat oranında artmıştır. Böyle bir dönüşüm nasıl açıklanabilir? Bu makalede Türkiye'de devlet kimliğinin dönüşümünün ulusal çıkar kavramsallaştırmasındaki bir dönüşüme sebebiyet verdiği iddia edilmektedir. Bu yeni devlet kimliğinde “Ortadoğu”nun ne manaya geldiği de değişikliğe uğradığı için, daha önce "görünmez" halde bulunan ekonomik çıkarlar görünür olmuştur.

Anahtar Kelimeler: Türk Dış Politikası, Ortadoğu, Sosyal Inşacılık, Devlet Kimliği, Çıkar Kavramsallaştırması

ORC-ID: A. E. Tüzgen 0000-0003-0117-905X 


\section{Introduction*}

In the decade preceding the Arab Spring, we have witnessed a rapprochement between Turkey and the Middle Eastern countries. ${ }^{1}$ We observed not only the replacement of highly militarized and securitized lenses of governments with less militarized ones, we also observe strengthening of economic and cultural ties among the countries of the region. Some of the indications of the new developments can be seen in the increasing number of official visits of policy makers between Turkey and the Middle Eastern states. Likewise, the number of the tourists traveled to Turkey from Arab countries and the amount of exports and imports between Turkey and the region have increased. ${ }^{2}$ What explains such changes?

Although there are alternative theories ranging from realpolitik of post-Cold War geostrategic considerations (Kardas, 2009) to interdependence of "trading states" of liberalism (Kirisci, 2009), I think a constructivist approach with the emphasis on the identity of respective actors has its unique contribution to make to our understanding of the change in Turkish-Arab relations. In this paper I argue that, without taking the change of identity in Turkish foreign policymaker elites and its relation with the change in interest conceptualization into consideration, it will not be possible to understand all of the dimensions of the rapprochement in the Turkish-Arab relations. More specifically, the focus of this paper is on the developments in economic relations in the decade preceding the Arab Spring because they are the primary target of rationalist analyses; and hence constitute a "difficult case" for other approaches. I argue that the dramatic increase in trade relations between Turkey and Arab countries is a result of a transformation in Turkish state identity under the Justice and Development Party. Although increased economic interaction and trade relations have obviously contributed to Turkish state interests, why had such levels of economic interdependence not been realized in the previous decades? I contend that one should focus on how interests are defined by state identities to understand the previous lack and current presence of intraregional trade relations. While the traditional Turkish state identity coded the Middle East as somewhere to refrain from, hence did not "see" an interest to interact with; with the transformation of that identity in the last decade, the region is viewed with more positive lenses, hence previously unseen economic interests have become visible. ${ }^{3}$

\footnotetext{
* I thank Ali Aslan, Stuart Kaufman, Mark Miller and Muqtedar Khan for their invaluable feedback to an earlier version of the paper.

1 With the exception of Israel. Turkish-Israeli relations have deteriorated after Israel attacked Gaza in December 2008. Until then, Turkey was mediating indirect negotiation between Syria and Israel.

2 The data concerning these developments are provided below.
} 
The organization of the paper is as follows: in the next section I explain the puzzle the paper addresses by looking at the data on international trade and foreign direct investment between Turkey and the Middle East. In the third section I discuss, from a constructivist theoretical point of view, how identity and interest conceptualization are related. The fourth section deals with the components of change in Turkish foreign policy both quantitatively and qualitatively, and analyzes how transformation of state identity leads to a change in economic interest conceptualization. The fifth section is conclusion.

\section{The Puzzle: Turkish-Arab Relations, 2002-2012}

Turkey's relations with Middle Eastern countries have improved significantly in the decade preceding the Arab Spring under the rule of current one party government of Justice and Development Party. Among many indicators of the improvement, economic relations have a special place. Compared to previous decades, especially the amount of exports and imports that has taken place between Turkey and the region shows significant increase. That increase accompanied by a decrease in the share of total economic trade of Turkey with the EU countries: in 1996 the share of the 6 biggest European trade partners in Turkey's exports was representing 43\% of all Turkish exports and MENA region was representing 14.3\%; in 2012 the share of European partners dropped to $27 \%$ and the share of MENA states increased to $34 \% .{ }^{4}$ Although the percentage share of European countries in the total trade of Turkey has decreased, that does not mean that in real numbers Turkey has decreased its trade with Europe. For example, although European states' share in exports decreased from 43 to 27 percent from 1996 to 2012, in real numbers it has increased from 10 billion dollars to 41.3 billion dollars. This shows two things: first, Turkey is not directing its economic relations towards the Middle East at the expense of European countries. That is to say, Turkey is not stopping or decreasing its economic ties with European countries; to the contrary Turkey is committed to increase its economic ties, in the decade preceding the Arab

ORC-ID: A. E. Tüzgen 0000-0003-0117-905X

3 The time span analyzed in this paper is between 2002, when JDP came to power, and 2012. I do not look at the post-2012 period because the effects of Arab Spring (started on the 17th of December 2010 in Tunisia), which has shaken the region from its very foundations and created unstable regimes (Libya), civil war (Syria), revolution and coup d'état (Egypt), started to be seriously felt after that year. An analysis that account for this unstable period in terms of economic interaction needs another research.

${ }^{4}$ All of the numbers regarding international trade are calculated from official data of Ministry of Economy of Turkey: www.ekonomi.gov.tr Six European countries are Germany, France, England, Italy, Holland and Spain. MENA states include Lebanon, Syria, Iran, Iraq, Palestine, Jordan, Saudi Arabia, Kuwait, Bahrain, Qatar, United Arab Emirates, Oman, Israel, Yemen, Egypt, Libya, Algeria, Tunis, Morocco, and Iran. 
Spring, with the European states too. That is why, in real numbers, it increased four times. Second, the share of Middle Eastern states in Turkish economy is increasing both in relative numbers and real numbers. This shows that, as it is the case with European countries, in real numbers, Turkey is increasing its economic interaction with the Middle Eastern states too. What is different from previous decades and from European countries is that the rate of this increase is much higher. While in real numbers exports to the 6 major European countries have increased 3 times from 2001 to 2012, it has increased 13 times with the Middle Eastern countries in the same time period.

Table 1. Turkey's exports to Syria and Iraq between 1990-2011 (in million dollars)

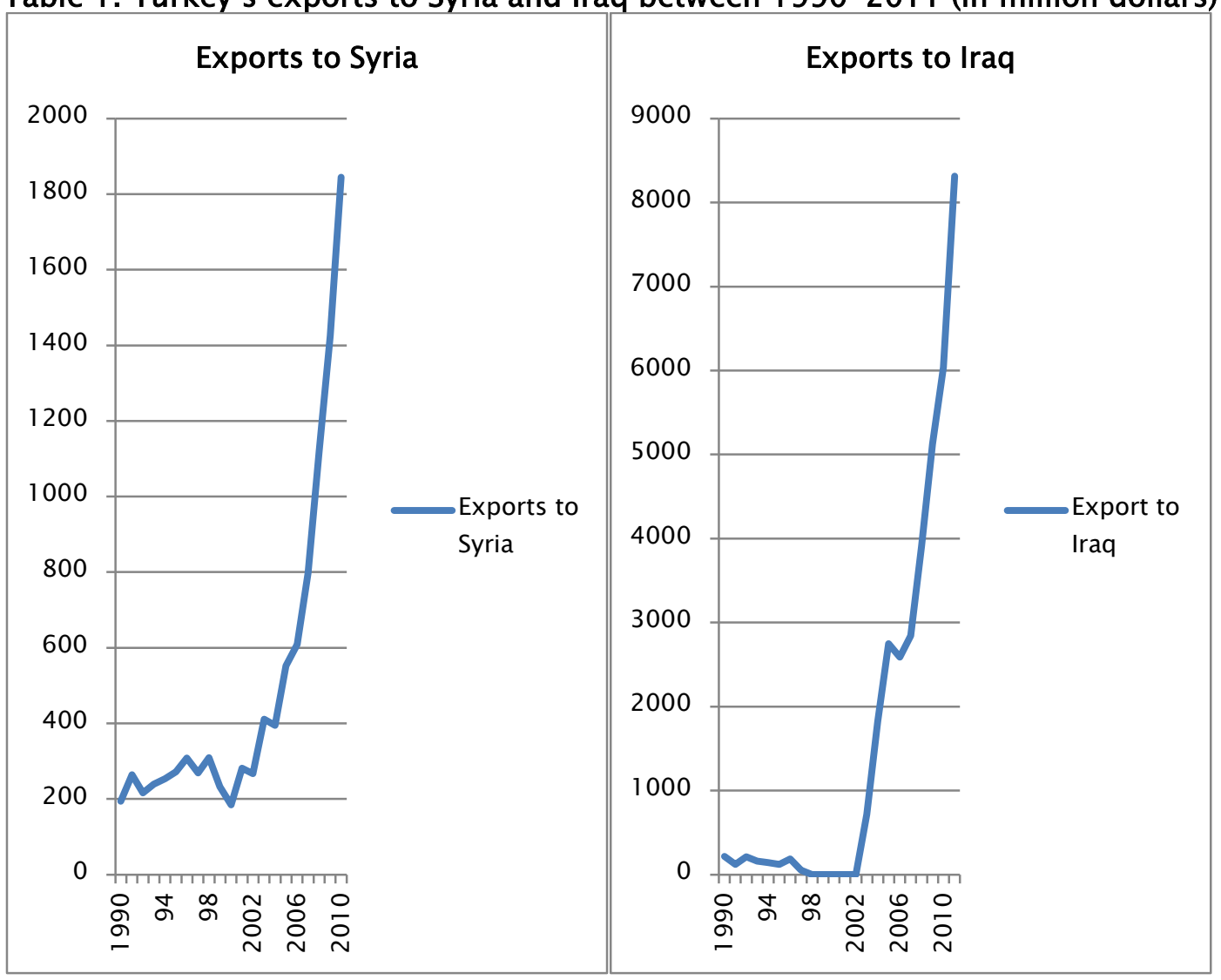


Table 2. Turkey's import from Egypt and United Arab Emirates 1990-2011 (million dollars)
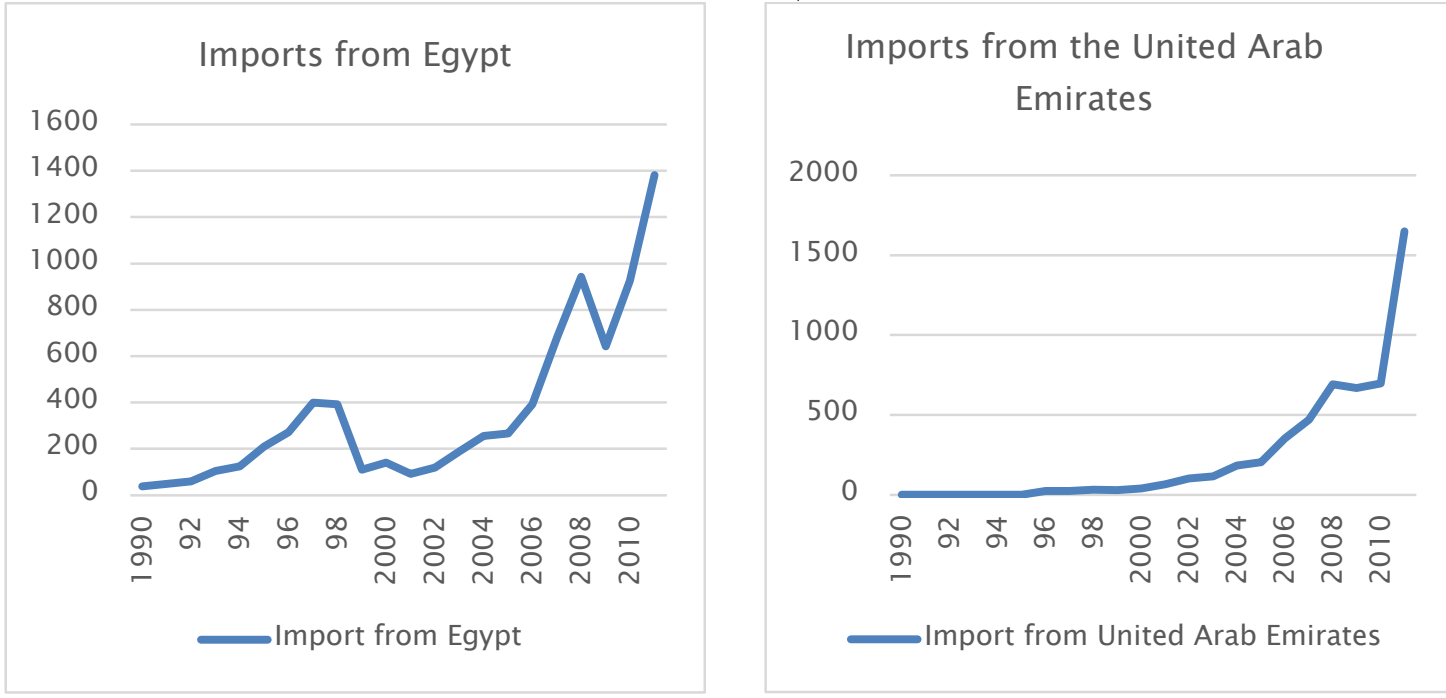

Table 3. Exports from Turkey 2001-2012 (billion dollars)

\begin{tabular}{|c|c|c|c|}
\hline Years/Countries & $\begin{array}{c}\text { 6 EU (Ger, Fr,Eng, Ity, Holnd, } \\
\text { Spain) }\end{array}$ & MENA & Total \\
\hline 2001 & $13,6(43 \%)$ & $4,3(13 \%)$ & 31,3 \\
\hline 2012 & $41,3(27 \%)$ & $51,8(34 \%)$ & 152,5 \\
\hline
\end{tabular}

Another indication is the growth of foreign direct investment invested in Turkey from the Arab countries. The amount of FDI from the Middle East, and especially from oilexporting Gulf countries increased from 2.6 percent of total stock of FDI in 2003 to 11.7 percent by 2012. The total amount of exports of Turkey to the MENA countries has increased from around 4.3 billion dollars in 2001 to 51.8 billion dollars in 2012 . Similarly, the total amount of imports from MENA countries to Turkey has increased from 5.1 billion in 2001 to 24.7 billion dollars in 2012 . 


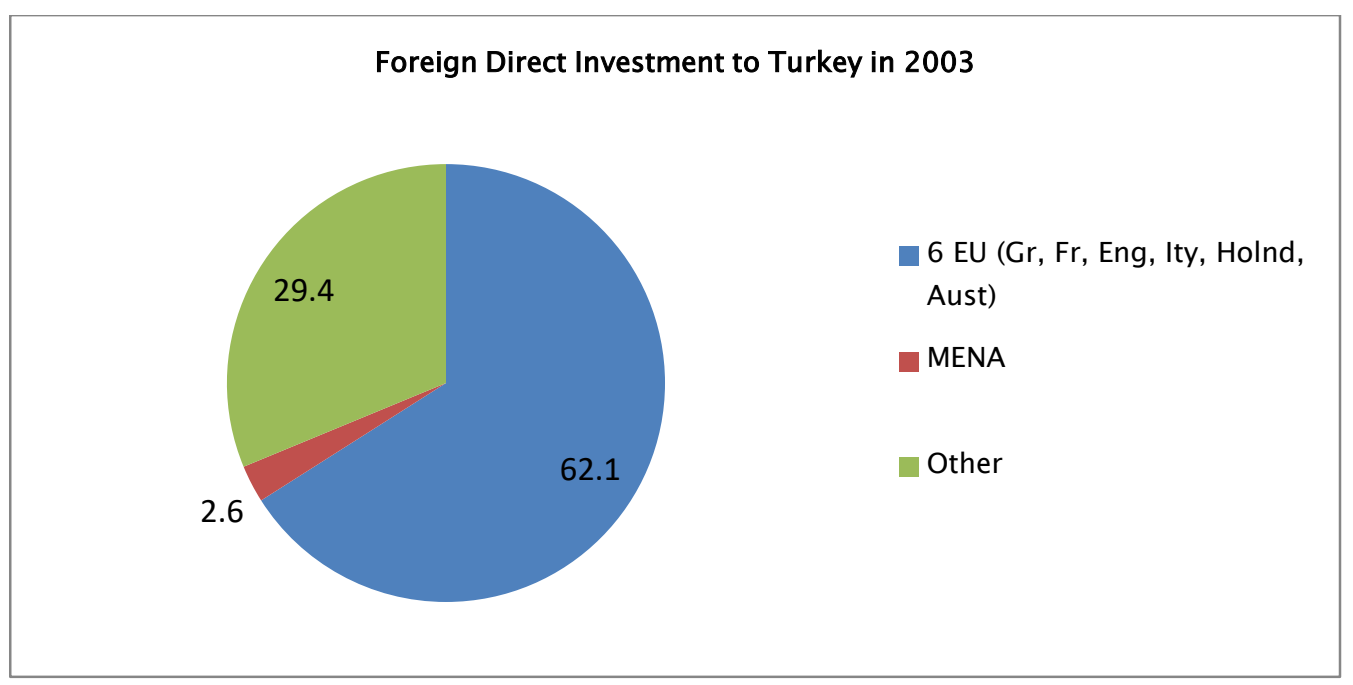

Figure 1. FDI to Turkey in 2003

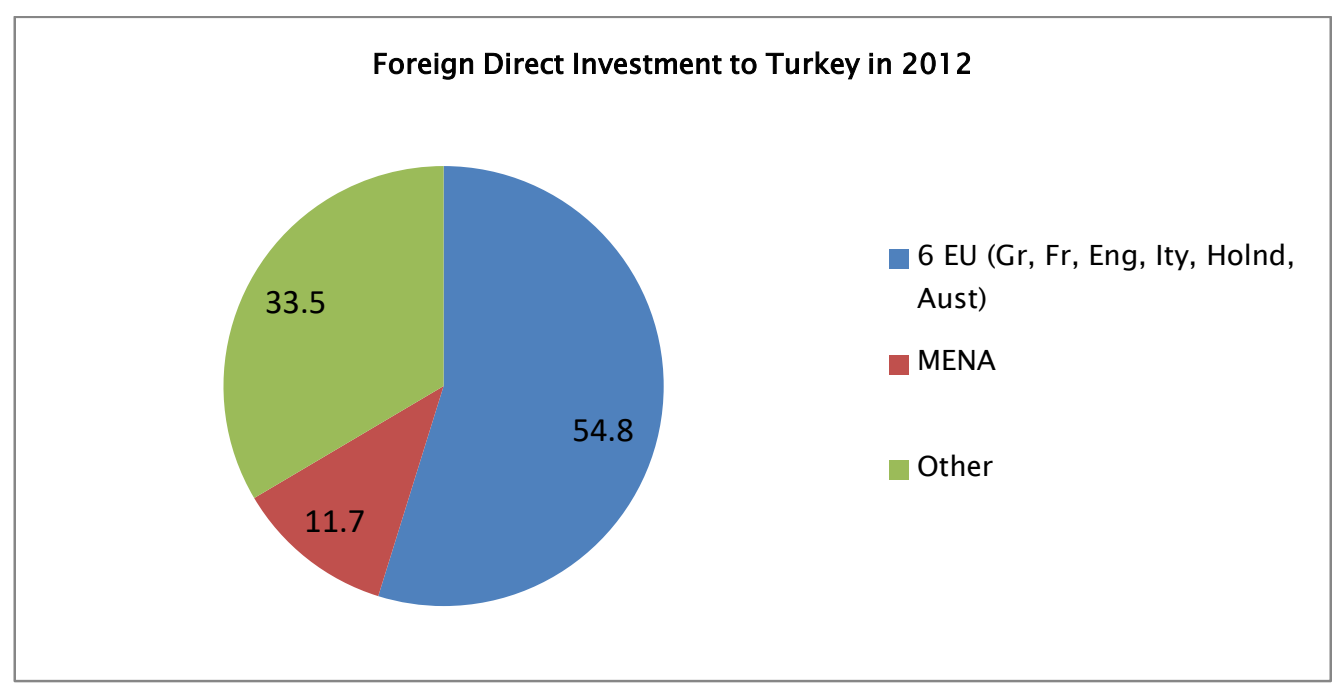

Figure 2. FDI to Turkey in 2012

Table 4. FDI to Turkey: 2003-2012 (billion dollars)

\begin{tabular}{|c|c|c|c|c|}
\hline FDI Years/Regions & $\begin{array}{c}6 \text { EU (Gr, Fr, Eng, } \\
\text { Ity, Holnd, Aust) }\end{array}$ & MENA & Other & Total \\
\hline 2003 & $5,2(61,2 \%)$ & $0,21(2,6 \%)$ & $3(29 \%)$ & 8,4 \\
\hline 2012 & $5,47(54,8 \%)$ & $1,16(11,7 \%)$ & $3,33(33 \%)$ & 9,9 \\
\hline
\end{tabular}


What explains such a transformation? How can previously unnoticed interests in the region be seen and taken advantage of? I contend that what made the unseen visible is the transformation of state identity in Turkey which has resulted into a transformation from traditional Turkish foreign policy making to the new (revisionist) one. Especially, new governing principles of foreign policy, new imagination of geography and reinterpretation of history enabled Turkish state to take advantage of international opportunities in economic relations.

\section{Theoretical Framework}

Although Brubaker and Cooper (2000) argued that it is time to let go of the concept of identity because of it is ambiguous character, one study on the use of identity in eight key IR journals between 1990 and 2002 demonstrated a significant increase in terms of the number of articles about identity published each year (Horowitz, 2002 quoted in Ashizawa 2008). In this section I try to find answers to the questions of how and why state identity is important to understand conceptualization of economic interest.

\subsection{Identity-Interest Nexus}

The importance given to the concept of state identity stems less for a desire to create an additional novel variable than for the necessity, according to constructivist scholars, to explain why states make certain preferences. The rationalist theories argue that states act in accordance with their national self-interest, the most important of which is survival (Waltz, 1979). Like the assumption of homo economicus in theories of economics, states, as rational actors, make a cost-benefit analysis in every action, and try to maximize benefits and minimize the costs. Explaining foreign policy decisions of states, according to rationalist theories, is possible through taking the national interest of these states into consideration.

One of the significant criticisms constructivist scholars direct against rationalist theories is based upon the problematic reliance on unquestioned nature of national interest. For constructivist scholars, rationalist theories assume, rather than explain, national interest (Chafetz, Spirtas and Frankel, 1998: 14). As a result, they are accused of using circular reasoning:

"The problem with the concept of national interest lies in its circular nature. Realists, reviewing past state policies, may declare these policies to have been in the national interest because they were executed by the state" (Ibid: 16) So how 
can the national interest be explained? Why does a state think that it has an interest to do $\mathrm{X}$ instead of $\mathrm{Y}$ ?

For constructivist theories, the answer lies in the concept of identity. If identity prescribes certain kind of behavior and motivate actors to undertake some policies, then states evaluate possible policy options through the lenses of such motivational factors. Jepperson, Wendt and Katzenstien (1996: 60) write that "actors often cannot decide what their interest are until they know what they are representing." To decide your interest, you have to know your identity. Interests presuppose identities (Wendt, 1999: 231).

Economic interest is one of the most significant components of national interest. Hopf (2012: 16) argues that states see in other states two forms of interests: strategic and economic. Similar to other forms of interest, economic interests cannot be explained without taking identities of states into consideration. That is because, as Wendt (1992) argues, there is no "portfolio of interest" for states, which includes economic interests too. The difference of economic interest from other forms of interests, however, is that it is the field where the economic thinking feels most confidence to itself. That is to say, the logic of market economy, which has been adopted by rationalist theories of international relations from theories of economics, with their assumptions of rational, cost-benefit analyst decision makers who act in accordance with the dictates of supply and demand curves, is expected to govern even more as far as economic interests of states are concerned. The underlying assumption here is that it is very logical to expect from the states to act in accordance with the "obvious" economic interest. Yet, the question is whether economic interests are, in fact, "obvious"?

The answer of constructivist political economy scholars is negative for this question (for an assessment of constructivism in economy, Seabrooke, 2007). According to Abdelal, Blyth and Parsons (2010), ideational factors play important role in international economic relations and to explain the interest perception of states, state identity is one of the important factors to consider. Abdelal (2001) provides a case analysis of newly independent post-Soviet states and asks the question of why different ex-socialist states' foreign economic policies differed so radically that cannot be explained by material conditions. The answer he provides is that nationalist ideology played an important role in policy preferences. According to Abdelal's analysis (2001), the states which have sizable nationalist movements and in which these movements are aligned with former communists of these states, the foreign economic policy is designed in such a way that would oppose a reintegration with Russia, no matter how costly this policy is in terms of material losses. 


\subsection{Four Models of State Identity: Theorizing Change}

I think there are four different ways constructivist scholars talk about the source of state identity and possibility of change. The first line of literature treats state identity as a function of interaction of states at the systemic level. According to that kind of analysis, structural factors are the most important determinants of state identity. States create the distinction between self and other through repetitive interaction with other states. One of the main proponents of this analysis is Wendt (Kubalkova, 2001; especially chapter 5). For Wendt (1994: 385), "identities and interests are in important part constructed by these social structures rather than given exogenously to the system by human nature or domestic politics." He defends the "states as unitary actors and interstate interaction is the basis of inter-subjectivity" which is criticized by some other theorists (Burchill, 2005: 203) such as Weldes (1999).

The second stream of identity theories within constructivist literature mainly focuses on international norm diffusion. Like the first one, this second stream also gives primary importance to systemic level. The focus of the change on that second line, however, is more on international norms and institutions. State identities are seen as shaped more by exogenous factors than internal dynamics within states. International norms advocated by international institutions create incentives for states to transform their identities through internalizing international norms. Martha Finnemore, for example, writes that "state interests are defined in the context of internationally held norms and understandings about what is good and appropriate" (quoted in Burchill, 1996: 199).

In contrast to the first two types of identity theories' emphasis on the international systemic factors, the third category of literature prioritizes the domestic components of state identity. According to that kind of analysis, the sources of state identity can be found in the societal determinants, such as historical background or ethno-cultural make-up of the population rather than exogenous systemic factors. As one of the most important representatives of this approach, Hopf (2012: 14) criticizes the first two categories of constructivism for not being "social" enough: "I propose to domesticize the social constructivist approach to international politics, to bring society back into social constructivism." That approach prioritizes the society over elites. Instead of focusing on policymakers as the creators of the identity and policy, they are accepted as an intermediary category through which the social identity is reflected onto the state behavior. Hopf (2009: 300), in his analysis of the Russian identity, for example, writes that his focus on the behavior of elites is instrumental because "they are the instruments through which the dependent variable of identity relations manifests itself." Rather than granting an exclusively independent agency to the individual elites, the identities of the 
policymakers are seen as a natural extension of social fabric. That means, to understand the state identity, which is represented by the elites, one has to look at the social identity, which is constructed in the history of the nation.

The fourth category of identity theories is similar to the third one in its emphasis on the endogenous factors within the country more than international systemic factors as the source of state identity. Nevertheless, it differs from the latter on the question of the relative independence of foreign policy makers from the societal constraining factors. In that regard the state is not treated as unitary actor as in the case of Wendt's constructivism; and the black box is opened. For the fourth stream of constructivist theory of state identity, "human agency is missing in structural constructivism" (Clunan 2009: 24). A criticism against Wendt can be found in Weldes who is one of the important names of the fourth model. She writes "meanings (...) for states are necessarily the meanings (...) for those individuals who act in the names of the states. And these state officials do not approach international politics with a blank slate onto which meanings are only written as a result of interactions among states" (Weldes, 1999: 9). Similarly, for Onuf (1998) "constructivism holds that social structures, by itself cannot serve as the basis for a complete account of identity. Agents and their behavior must be considered." The role attributed to the policymakers in this model is about the influence of the elites to transform, redefine and interpret the state identity.

It also envisages contestation over the definition of state identity among various factions of the elites who have differing projects of identity to become predominant in the state. In that regard the state identity "may not be necessarily shared by other individuals outside the policymaking process. Nor does it mean to represent what can be regarded as an agreed concept of state identity by the government or the society as a whole" (Ashizawa, 2008:576). To address this issue, Clunan makes a differentiation between "self-images" and "national identity." According to Clunan (2009: 14), "self-images" are contesting identities of different elite groups. When one of these elite groups achieves supremacy over others, this group's self-image becomes the representative of state identity. In other words, there is a constant contestation within the society on the question of whose project would be reflected as the national identity. Among others, one way to achieve this is to relate one's conception of national interest to "established, socially ascribed ideal about the identity of the state" (Burchill, 2005: 197). Keeping this theoretical discussion in mind, the next section analyzes the change in Turkish state identity and argues that the forth model of state identity change in constructivist theory captures the transformation better. 


\section{Components of Change: Turkish Foreign Policy}

Traditional Turkish foreign policy was designed on the grounds of the new nation-state, which was established in 1923, with the rejection of the imperial past of the Ottoman Empire. Its main priorities were preserving the integrity of the country, following the Westernization path, consolidating its strictly secular state system, and surviving in a tension-ridden environment. Foreign policy was designed to keep Turkey out of regional problems; and at the same time keep other powers out of Turkey's internal politics. Famous statement of Ataturk, the first president of the new republic, "peace at home, peace abroad" was implying that "we will not intervene in anywhere, and nobody should intervene in us." In other words, Turkey was trying to give a message to great powers that Turkey has renounced its rights and aspirations concerning the lands it lost in the WWI and War of Independence; and would behave as a non-imperial, ordinary Westphalian sovereign nation-state. Except for the brief period between 1955-60 under Democrat party rule, one can explain many foreign policy decisions in major events related with Turkey in world politics until 1990s in such a framework. Turkish foreign policy during World War II, her quest for EC membership, neutrality during Iran-Iraq war of 1980-89 can be quoted as examples of the application of the traditional Turkish foreign policy (Mufti, 2002).

It has been observed that with the current ruling party since 2002, many of the principles of foreign policy making have experienced a dramatic change. Adherence to unidimensional Western path and rejection of relations with former Ottoman lands are transformed into a multidimensional foreign policy. Another change in the new period is re-appearance of Muslim identity in foreign policy. New ties with the Middle Eastern countries are established; and Islam as a common religion is more pronounced. An increasing emphasis is made on the common past and shared geography. Instead of defining itself primarily as a Western state, Turkish foreign policy makers adopted a new kind of identity which is more inclusive, and more accommodating of differences. Hence, the Arab identity, which was previously juxtaposed to Turkish identity, and which was representing a backward stage in the history of progress in the minds of Turkish elite who want to imitate Western developed nations, has started to be perceived in more positive terms.

Before going into the components of state identity change and its influence on foreign policy, in addition to data concerning economic relation provided in the second section of the paper, we should explain, what kind of empirical evidence lead us to believe in a 
change from traditional to new foreign policy. To this end, next section shows the change in numbers.

\subsection{Quantitative Change: Some numbers about Turkish Foreign Policy}

I think we can demonstrate the quantitative change in Turkish foreign policy in the decade preceding the Arab Spring by looking at five areas: the pro-active role in ageold problematic issues of Turkish foreign policy and crisis in international society, active engagement in the international organizations, the policy of abolishment of visa requirements with various countries, the number of bilateral and multi-lateral agreements that Turkey signed in that decade compared to previous era, and policy of increasing numbers of Turkish embassies in the world to increase representation of Turkey abroad.

To begin with, different from the previous decades of traditional foreign policy, the decade preceding the Arab Spring have witnessed a change in the number of Turkish interventions in the problematic issues between Turkey and neighboring countries. The problems with Armenia which stem from genocide accusations, the question of Cyprus which causes disagreements with both Greece and the EU, and problems with Iraq and Syria which are mainly about the support these countries give to PKK terrorist organization are some of chronic problems in Turkish foreign policy. The traditional foreign policy stance concerning these issues is the defense of status quo. The new foreign policy, on the other hand, displays a striking difference from the traditional Turkish foreign policy on these chronic problems and favors following an activist route to solve them. As an example, Turkey's stance concerning Cyprus question has significantly changed. The new foreign policy makers acted cooperatively with regard to the then UN secretary general Kofi Annan's plan. The plan was accepted by Turkey and taken to referendum in Cyprus in April 2004. While Turkish Cypriots accepted Annan plan by $65 \%$, Greek Cypriots rejected it by $75 \%$. What is of historic importance about the Cyprus case is not about its end result. Rather it represents radical transformation in Turkish foreign policy which has not demonstrated any significant efforts for its solution until the new era.

Second indicator of change in Turkish foreign policy is about the role Turkey plays in the international organizations. The new foreign policy's projection of Turkey is a state that has active ties with as many international organizations as possible. Contrary to previous tradition which favors being member of only a limited number of IOs which are of strategic importance to Turkey such as NATO and OIC, in the new foreign policy 
participating even geographically remote IOs is deemed important. This new stance is reflected in Davutoglu's speeches (2012b):

We established the Turkish World Council. The African Union has announced Turkey as one of three strategic partners alongside with China and India. We established strategic dialogue with Gulf Cooperation Council; and attained observer status in the Arab League. From Caribbean to Pacific islands, ASEAN, CARICOM and MERCUSOR being the most important ones, we are either strategic partners or observer state in almost all international organizations. (...) Now there is almost no regional or international organization in which we are not represented.

Another numerical indicator which shows the quantitative change in the new Turkish foreign policy is about the bilateral and multi-lateral agreements that Turkey signed, especially with neighboring countries in the last 10 years. Through what is called "High Level Strategic Cooperation Councils" formed with 18 countries since 2006, Turkey initiated creation of many new cooperation treaties with its neighbors. As an example, while in twenty-two years between 1980-2002 only 13 international agreements were signed between Turkey and Syria, between 2002-2012, Turkey and Syria signed 50 agreements (iHA, 2012). The numbers with other countries are also illuminating: 48 with Iraq, 40 with Egypt and 29 with Russia. In total, since 2006, 419 agreements were signed between Turkey and member states to cooperation councils (Directorate of Public Diplomacy, 2015).

Last two important quantitative changes in the Turkish foreign policy is about the number of Turkish embassies abroad and the abolishment of visa requirements with different countries. Turkey followed an active policy of increasing the number of its foreign missions in the countries in which it had not had diplomatic representation. Before 2002, Turkey had 94 embassies abroad; by 2013 the number is 126 . Likewise, while in the pre-2002 period Turkey had 190 Consulate Generals in the world, it has 220 in 2013 . A similar increase has been observed in the number of countries to which Turkish citizens can travel without visa. In order to increase cooperation with other countries, one of the aims of the new Turkish foreign policy is to increase mobility and transportation between Turkey and other countries. Between 2009-2012, Turkey signed visa abolishment agreements with 21 countries including Lebanon, Libya, Syria, Russia, Albania, Indonesia, Qatar, Ukraine, Serbia, Tunis and Sudan. 


\subsection{Qualitative Change: Components of State Identity}

These quantitative changes are indicators of a qualitative change in Turkish state identity. Remembering our puzzle at the beginning of the paper, exactly which factors of the new foreign policy can explain the formation of new economic ties with the Middle East and perception of new sources of economic interest which were unnoticed by the previous model? I think three components deserve particular attention to answer this question: change in the governing principles of foreign policy making, new perception of geographical space, and new assessment of historical background.

\subsubsection{Change in Principles: From Hobbesian Anarchy to Lockean Cooperation}

The first component of transformation in Turkish foreign policy concerns the principles according to which foreign policy decisions are made. We observe a transition from traditional foreign policy making to the new foreign policy with respect to the general principles and ordering rules of politics. While the concerns of the traditional policy makers are shaped in a Hobbesian anarchy, the new principles that govern new policy making are closer to Lockean anarchy with their emphasis on cooperation and positive sum games. The principles that govern the traditional foreign policy making towards the Middle East, are formulated by Malik Mufti (2002) as reserve rather than engagement, neutrality rather than alignment, rigid adherence to the status quo rather than flexibility and compartmentalization rather than integration.

What do these terms mean on the ground? Reserve rather than engagement means "eschewing interference in the domestic affairs of the Middle Eastern countries" (Mufti, 2002). Turkey consistently followed the policy of non-engagement in the internal politics of Middle Eastern countries and in the bilateral problems of these states. An example of the reserve principle is Turkey's non-engaging stance in Syria-Jordan or Syria-Lebanon conflicts. Neutrality rather than alignment means avoiding "becoming identified too closely with any single Middle Eastern state and avoiding being dragged into regional conflicts" (Ibid, 2002). An example of neutrality policy is Turkey's nonaligned stance in the Iran-Iraq war of 1980-89. Adherence to status quo rather than flexibility refers to opposing attempts to change regional balance of power especially through forming hegemony (for instance, through Pan-Arabism). Lastly, compartmentalization rather than engagement is explained by Mufti (2002: 82) as "avoiding linkage between Turkey's Middle East policies and its relations with the western powers." While Turkey tried to avoid being seen as a western "agent" in the region, it tried to avoid to be perceived as Middle Easterner in Europe 
Berdal Aral (2001: 74) also adds elements of xenophobia and rejection of Islam to these principles. According to Aral in the traditional Turkish foreign policy, we can observe xenophobic elements such as seeing all non-Turks as enemies and conspirators against Turkey. Similarly, the state identity is established in opposition to Muslim identity. When we add these governing principles of Turkish foreign policy up, we can have a sense of what kind of international environment the policy makers had imagined. That is to say, these principles were stemming from a mind-set that constructs the international world as hostile, threatening, and dangerous. Hence, relations with others are seen as zerosum games which is the characteristic of Hobbesian form of anarchy

When we look at the new foreign policy making, on the other hand, from the very beginning of the rule of the current government, the newly elected political elite have announced that they would change the principles of the traditional foreign policymaking with a new vision. They consciously distanced themselves from the way the previous policymaking elite conduct foreign policy. Then-foreign minister Professor Ahmet Davutoglu, who is considered to be the chief architect of the new vision, has declared the principles that they would use in their foreign policy decisions. Davutoglu (2015) writes that there are some methodological and operational principles that govern the new vision. The methodological ones are the "visionary" approach to the issues instead of the "crisis-oriented" attitude that dominated foreign policy during the entire Cold War period; to base Turkish foreign policy on a "consistent and systematic" framework around the world; and the adoption of a new discourse and diplomatic style based on Turkey's soft power. What these principles mean is this: the new vision aims at establishing a novel framework of policy making. It is directly against the traditional vision's neutrality and avoidance principles. What the new vision accuses of the traditional style is that the latter allows international crises to dominate diplomatic relations with others. The new vision offers that we can find different subjects of cooperation with these countries without making the problematic topics our central concerns. Lastly, the third principle of adopting "a new discourse and diplomatic style based on Turkey's "soft power" reinforces the previous point. This principal projects that highly securitized lenses of traditional foreign policy should be replaced with soft power. Economic cooperation, tourism, humanitarian relief, education policies etc., which constitutes the soft power of a country, are given more importance.

The operational principles of the foreign minister include the principle of zero problems towards neighbors; adherence to a multi-dimensional foreign policy; and rhythmic diplomacy, which aspire to provide Turkey with a more active role in international relations (Davutoglu, 2015). Similar to methodological principles, the basic aim of these 
operational principles is to open space for diplomatic relations with different countries other than national security consideration. The principle of zero problems towards neighbors is the product of a very different mind-set than the traditional one. The question whether or not this is realizable withstanding, to imagine that Turkey can achieve zero problems with neighbors is itself a revolutionary thinking. Likewise, multidimensional foreign policy shows that an imagination of international relations which is not based only on security is possible. In other words, while traditional foreign policy was uni-dimensional in the sense that security was the single most important concern for Turkey, with multi-dimensionality which includes economic cooperation and educational programs, for example, Turkey started to imagine a non-Hobbesian international system.

Apart from the concrete meanings of these principles, I think what is important in such a principled formulation is that, the new elite, as it was discussed by Clunan and Weldes above, have a conscious and intentional desire to transform the vision of Turkey. This can be seen as a transformation of identity because, as the definition of identity describes, these new principles attempt to change the answer to the question of "who we are" and "what the Turkish state is." It is an attempt to distance new elites from the past answers to these questions. The process, however, does not work so neatly all the time. The political actions of the new elite have been under constant criticism by the representatives of the former vision. As a vehement defender of the neutrality and noninterventionist traditional foreign policy, the head of main opposition party CHP, Kılıçdaroğlu states that the "AK Party government's "interventionist" policies towards Syria (and its proximate enviroment in general) are at odds with Turkey's traditional [read Kemalist nation-state] foreign policy principles" (quoted in Aslan, 2013: 29) Criticizing the governments engegament policies in the Middle East, former head of CHP Baykal (2006) says: "We have been making foreing policy decisions in this region for decades; but we have never become part of the problems. If we choose sides in these conflicts, it would create serious problems for Turkey."

As far as the relation between the new identity and economic interest perception is concerned, there are clear references in the new vision to the importance of economic ties with the neighboring region in foreign policy making, which was previously dominated by a more security-oriented framework of hard power. Davutoglu (2015) states that:

Turkish diplomats and politicians have adopted a new language in regional and international politics that prioritizes Turkey's civil-economic power. (...) There is a 
developing economic interdependence between Turkey and its neighboring countries. (...) Turkey's trade with its neighbors and nearby regions has substantially increased in recent years. (...) Turkey's regional policy is based on security for all, high-level political dialogue, economic integration and interdependence, and multicultural coexistence.

Hence for the new vision, there is a conscious motive for the policymakers to put special emphasis on economic relations. Increasing economic interaction and creation of economic interdependence among neighboring countries are seen as important parts of the new Turkish state identity. In other words, one of the answers to the question of "what Turkey is" is that "it is (should be) a country with strong trading ties and economic interdependence with neighboring regions." The new Turkish state identity is constructed through these answers. Addressing to the Turkish ambassadors and personnel of the foreign ministry Davutoglu (2011) says:

We have to act like businessman as a requirement of the rise of our economic power. You are all businessmen on behalf of the country. Helping one of Turkish companies to do job abroad is equivalent to contributing to power of Turkey. (...) Our ambassadors have to act as businessmen when necessary.

\subsubsection{Change in Geographical Imagination: Neighbors as Friends}

The second component of the transformation in state identity that enables the elite to take advantage of previously underexplored economic interests is the new imagination of the neighboring geographical space. In the traditional foreign policy, the relations with neighboring countries is conceptualized in a perfect state of anarchy in the realist meaning of the term, which includes perception of constant threat, creation of security dilemmas and theorizing relations as a zero sum game. In the official education curriculum, it was merely seen as a truism to say that "Turkey is surrounded by enemies from four sides." 5 Turkey had border problems with Syria, Kurdish "threat" from Iraq, accusation of Armenian genocide and closure of borders with Armenia, threat of Islamic regime from Iran after the Iranian revolution, disputes over Aegean islands with Greece, and problems of Turkish minority in Bulgaria. In such a conflict-ridden perception, nation-state borders are taken very seriously by the policy-making elite.

As far as the relations with the Middle East are concerned, after its foundation in 1923, with regard to the future projects of the Turkish republic, Middle East was representing the opposite polar of Westernization, whereas Turkish state was trying to be part of the Western club (in the institutional forms of NATO, Customs Union, or EU). The two -

\footnotetext{
${ }^{5}$ One can look at the secondary school textbooks, especially the course on "National Security" at $8^{\text {th }}$ grade.
} 
Middle East and Europeanization - were constructed as two mutually exclusive identities in the minds of the policy makers. In addition, compared to other perceived threats to Turkey, the Middle Eastern identity, which can be understood as the combination of the Ottoman past, Islam, and anti-Westernism, is the most feared and disliked because it is the most powerful candidate to replace the new identity. That is to say, it was seen as the most powerful opposition because it has the highest probability to take the place of the then new state identity.

The greatest threat to the Self is a comprehensive alternative identity, an Other that can plausibly be understood as a replacement. (...) Perhaps the most threatening Other is the closest Other, closest in the sense of being able to replace the Self more easily than any alternative. (Hopf, 2012: 8)

Because of these reasons, the Middle East is coded more as threat than as a source of interest and opportunity. This mode of thinking can be found, for example, in the speech of a retired general of the Turkish army. Gen. Cetin Doğan asked "what was our business in Yemen?" referring to Ottoman expansion in the Middle East and the bloody wars fought in the WWI. He is reflecting a mind-set which believes in no historical and cultural ties between Turks and Arabs, between Anatolia and the Middle East. This is also used as a criticism against government's policy of sending soldiers to peace missions in Afghanistan and Lebanon.

When we look at the new foreign policy vision, whereas the traditional foreign policy was unwilling to challenge the strict borders of the nation-state, the new identity has replaced that geographical imagination with more "porous borders." 6 Theoretically this was justified on the conceptual transformation of the role of Turkey from "bridge" to a "center-state" (Davutoglu, 2001). What the bridge analogy, which was popular in the early 1990s, was referring is that Turkey, thanks to its geographical location between Europe and Asia, should play the role of connection point between two sides. That included material transfers, such as oil pipelines, as well as cultural ones, such as bringing democracy to the Middle East. New identity rejected the bridge analogy because it was accused of being merely instrumental. Instead, the new elite proposed that Turkey is a "center-state." What that meant for economic transactions is that, instead of accepting a transitory role, Turkey should establish economic relations with every neighboring region independent of its ties with other regions. In other words, rather than being a transit country between east and west in their economic relations and being

\footnotetext{
${ }^{6}$ For the elaboration on the concept: Benhabib (2004).
} 
an object, Turkey should become a subject itself to improve its own relations with other countries:

When Turkey's role in the international system was defined, this was usually the role of "bridge." In fact, the sole function of a bridge is to connect two entities and carry over one side to the other; an actor defined as a bridge is not regarded as an independent actor with agency. Embracing this definition had led us to be perceived as imposing the values of the West when we establish relations with the East and as an Easterner carrying the negative attributes of the East when we establish relations with the West. In this new period, Turkey has to be defined as "center" state, not a "bridge. (quoted in Aslan, 2012: 167)

The new vision wanted to challenge traditional conceptualization of border as dividing lines between countries and peoples. Davutoglu (2010a) said "the borders between Turkey and its neighbors will not be walls but doors. It is not possible to separate Mosul and Mardin; Aleppo and Antep. We are integrated societies." The practical realization of the criticisms against strict nation-state borders and bridge analogy is shown in the reciprocal removal of visa requirements with several countries, including Syria, Lebanon, Jordan, Libya. The rationale for these policies is explained by Davutoglu (2010c) in his statement that "we want all borders to be opened." The change in geographical imagination can also be observed in the following speech of the former foreign minister (2013):

Without going to war with anyone, without declaring enemies and without disrespecting anyone's borders, we will be connecting Sarajevo to Damascus and Erzurum to Batum once again. This is the source of our strength. They may now appear to be separate countries; however 110 years ago Yemen and Skopje were both part of the same country. The same can be said for Erzurum and Benghazi.

With regard the Balkans, Davutoglu (2013) says:

"we want Edirne, Thessaloniki, Plovdiv, Skopje, Sarajevo, Pristine, and Belgrade to be re-united in a zone of friendship." Similarly, Erdoğan, states that "we will tear down artificial boundaries and superfluous walls between Turkey and the Middle East and its societies" (quoted in Aslan, 2013: 29).

One should also note that the solidarity among Muslim people traditionally was referred by the word "brother." The case of Middle Eastern states deserves particular attention in the new geographical imagination. This is because, as discussed above, Middle East was 
representing the closest, hence most threatening Other, to the Turkish self for historical reasons.

This transition from threat to friend corresponds to Chafetz et al.'s characterization of identity relations form complete negative to complete positive ones. They (1998: 10) write that:

Identification exists along a continuum from absolutely negative to absolutely positive. Absolutely negative describes a zero-sum conflict situation. Absolutely positive identification describes some family relationships and the bonds between soldiers during combat. (...) Actor A can have, among its identities, "adversary of actor B." Over time that identity may become "friend of actor B." In that case we say that A'S level of negative identification with $B$ decreased and the level of positive identification increased.

The criticism of Gen. Dogan about Ottoman involvement in Yemen quoted above, and involvement in missions in Afghanistan and Lebanon is responded by Erdogan. His words reflect a very different world view from the traditional foreign policy in terms of the geographical imagination. Referring to soldiers who lost their lives in the war of Dardanelles in 1915 in the WWI, Erdogan (2012) says:

If you go to the martyrs' cemetery in Çanakkale, you see the names of martyrs from Bosnia and Kosovo. Nobody asked to Bosnians and Macedonians "what was your business in Çanakkale? What heedlessness! They came here for their brothers; and defended these lands shoulder to shoulder. We will reach remotest places for the sake of friendship and brotherhood. Despite the short-sighted political parties which do not look outside of Ankara we will continue to be with the world. I am greeting our soldiers who serve in Afghanistan, Kosovo, Lebanon and Somalia.

\subsubsection{Change in Interpretation of History: Past as a Positive Resource}

The third component of the new identity which enabled to open a new era in terms of the economic relations with the Middle Eastern countries is the reinterpretation of the historical experience. In the traditional foreign policy vision, history is evaluated with negative feelings, which is because Turkish Republic is established on the basis of rejection of the Ottoman past. Official ideology of the Republic concerning the Ottoman Empire can best be illustrated by the way students in the elementary schools are indoctrinated. One of the famous poems in the official curriculum states that: "Today a 
parliament is established / And immediately the sultan is expelled out."7 After the establishment of the Republic both the Ottoman sultan and all members of the dynasty including women and children were sent to exile. The revolutions that took place after the establishment of the Republic such as the change from Arabic script to Latin script, change in the official dress code, and change in the calendar etc. were all aiming at severing the historical ties with the Ottoman Empire.

Combined with the discussion of geographical imagination discussed above which is about a constant threat perceiving social psychology, compared to other regions in the world, the status of the Middle East is more negative historically in the minds of Turkish policymaking elite. There are a number of reasons for this. As far as Turkish state identity is concerned, the first one is that the Middle East is associated with the Ottoman imperial past from which the republic is trying to free itself. In contrast to multi-ethnic, multi-lingual, multi-religious order of the empire, the nation state was aiming at the creation of the unified population of the nation-state. The historical memories from the WWI about the Middle East are very negative in the minds of traditional Turkish foreign policy makers. Because of the bloody wars and losses of thousands of soldiers, traditional idiom for the Middle East among Turkish elite is: "the swamp of the Middle East." Even the head of Kurdish nationalist party uses the phrase. Concerning Turkish military's operations in the Northern Iraq against the PKK camps, Ahmet Turk (2007), then head of Kurdish nationalist party says that "The operations would drag Turkey to the swamp of the Middle East." Although ideologically from the opposite of political spectrum, similar concerns are expressed by the head of Republican People's Party leader, Kemal Kılıçdaroğlu. Criticizing government's foreign policy concerning the Mavi Marmara incident, Kılıçdaroğlu (2015) says: "In one way or another Turkey is tried to be dragged into the swamp in the Middle East."

The second reason why the status of the Middle East is negative historically in the minds of Turkish policymaking elite is that, in terms of the tension between secularism and sharia rule, the Middle East was representing the latter, while the republic was trying to consolidate its strictly secular character. Many secularist politicians and journalists say proudly that "Turkey is the only secular democracy in the region, and this is its most important asset." 8 Increasing involvement in the Middle East and the government's emphasis on religious ties with the peoples of the region led opposition parties (and

\footnotetext{
7 Poem by Saip Egüz. It is the most frequently cited poem in the celebrations of the establishment of the Republic until recently.

8 See for example, Turgut (2012).
} 
alternative elites) to defend that foreign policy has to be conducted on secular grounds. Criticizing foreign policy decisions of the current government concerning the Middle East, a former minister of foreign affairs Mümtaz Soysal (2013) argues that not only in domestic politics but also in international politics secularism (/aicite) should be the governing principle: "To accept secularism as the unchanging principle of the foreign policy will prevent other ambitions to influence decisions than the national interest." Thus, the perception of history combined with the specificities of the Middle East in this perception directs traditional policy makers into a negative attitude toward both the history and the Middle East. As a representative of this vision former Chief of Staff General Başbuğ emphasizes Turkey's secular character as opposed to its Islamic ties:

In the context of the Greater Middle East Project, in some circles Turkey is presented as a model. Turkey does not have a claim to be a model. From its establishment, the Turkish Republic has been a secular, democratic, and social state, governed by the rule of law. Some talk of Turkey being an Islamic state. Secularism and a moderate Islamic state cannot coexist. (quoted in Aslan, 2012: 166)

In the new vision, however, the transformation in the state identity accompanied a change in the mainstream historical account of the tradition foreign policy making. The Ottoman past, which is treated with neglect in the traditional model, is started to be seen as glorious past shared by other countries of the region. When asked about the reason why Turkey is very much involved in the Syrian crisis, Erdogan responds:

"The answer is easy: we are a country which is established on the heritage/legacy of the Sublime Ottoman State [traditional name of the empire]. We are the grand children of the Ottomans and the Seljuks" (quoted in Ergin: 2012).

As discussed by Zehfuss (2002: 85), the Other for the Self sometimes can be a historical image; which is an "Other within the Self." Nazi Germany, for example, is considered to be the Other of post-Nazi democratic German Self. Similarly, in the traditional account of Turkish foreign policy, the Ottoman Empire was accepted to be the Other of the republican Self. The new state identity, however, is constructed in such a way that it also includes the Ottoman legacy. Although we do not see any reference, at least in a positive way, to former Ottoman lands in the traditional foreign policy making style, both Erdogan and Davutoglu express their positive feelings towards the Ottoman experience which represent historical cooperative ties to the peoples of the region: 
With those whom we were together between 1911 and 1923 and in the lands where we experienced this togetherness, we will meet with all of these brothers of ours in these lands in 2011 to 2023 as a new big consolidation. The critical concept of the coming era is this. Restoration and consolidation. (Davutoglu, 2011)

One should remember that the years 1911 to 1923 represent the dissolution of the Ottoman Empire through wars in Libya in 1911, Balkan wars, the First World War, and the war of independence that resulted into the establishment of Turkish Republic in 1923. Similar feelings are expressed by the Erdogan (2011). He emphasizes the historical, borderless togetherness with the countries in the Middle East as a positive background:

Our history is very much related with the history of the region; and our shared history is divided by the WWI when new borders were drawn. You cannot read history of Turkey separate from the history of Morocco, Algeria, Tunis, Libya, Egypt, Palestine, Jordan and other countries of the region. (...) How did these states come into being, how the borders are drawn, how their administrations are shaped? (...) Turkey is a country which had been part of the process 100 years ago that led to these transformations.

He criticizes former state policies concerning history which de-emphasized these ties: "We were made uninterested in our history. I want to go one step further: We were forced to forget our history" (Ibid.) As a solution to contemporary problems, Erdogan proposes re-reading history, which was tried to be forgotten by the former elites:

Without knowing Ottoman Empire, without understanding the battles of Canal and Hijaz (of the WWI), it is impossible to understand the question of Palestine today. Without reading the history of the Ottoman Empire, it is impossible to analyze the problems in Kosovo, Bosnia, Macedonia, Montenegro, and Serbia. Without reading the Turkish history, you cannot write the history of the Balkans, Caucasus and the Middle East. (Ibid.)

As far as economic relations are concerned, this new identity, which is reconciled with the history, manifests itself in linking the current economic developments with past historical examples. That is to say, the economic interaction between different regions within the empire which later became parts of different nation-states is cited to demonstrate that an alternative imaginary is possible. The borderless economic interdependence of historical experience is projected to the current and future designs of economic interaction. Concerning the borders between Turkey, Syria and Iraq, Davutoglu (2010b) states that: 
States, which were within the same borders in the past four thousand years, have been created, such as the borders between Turkey and Iraq or between Iraq and Syria. ... We can reunite in peaceful ways. The rule of history still continues. We are all mutually rediscovering our neighbors.

In the second Turkish-Arab Council meeting of foreign ministers in Damascus, Davutoglu (2009) stated that the region should strive to achieve "economic integration." Similarly, between Turkey and Northern Iraq a full economic integration project is tried to be carried out (Yeni Safak, 2010). The importance of historical legacy in terms of economic integration can best be observed in a speech of Davutoglu (2012a): "In the regions which we lost between 1911-23, we will meet with our brothers and sisters there between 2011-2023." The vision of economic integration with the Middle East can become possible only by a reevaluation of the question of "who we are." Hence, two historical narratives represented by two alternative identities see different things when they look at the same world.

\section{Conclusion}

One of the significant criticisms directed against rationalist theories of international relations by the constructivist scholars is that rationalist theories assume rather than explain many of the important concepts in understanding the political world. In a similar vein, constructivist view on the concept of economic interest of states tries to demonstrate that interests are not given from the outside world but constructed within inter-subjective and interactive processes. State identity deserves particular attention in this respect. Nevertheless, constructivist scholars do not have a consensus on their theorization of state identity. I have argued that there are four main lines of thought within constructivist state identity literature. While two of them (here represented by Wendt and Finnemore) emphasize exogenous - ie: international systemic - factors, the others (represented by Hopf and Weldes) prioritize endogenous factors. While first of the endogenous factor theories focuses on society, the second attaches more importance to the elites. In my case study of Turkish-Arab relations, I found it more useful to employ this last type of theory.

I have argued that the change in Turkish state identity enabled foreign policymakers to see new opportunities in the neighboring regions that were previously dominated more by threat perception. More specifically three aspects of the new identity - new principles, new geographical imagination and reinterpretation of history - transformed the relations of Turkey with the countries in the Middle East. This new era manifested itself, among many others, in the field of economic relations. 
A final concluding remark: Although Middle East has a unique place in the new Turkish state identity, the case study analyzed here does not imply that the new vision of foreign policymaking is based on developing good relations only with the Middle East. The three components of the transformation - new principles, new geographical imagination and reinterpretation of history - provide fertile grounds to improve relations with other regions as well, such as the Balkans and Caucasus. Yet, understanding exactly how these factors have been working in other regions requires further research.

\section{References}

Abdelal, R. (2011) National Purpose in the World Economy: Post-Soviet States in Comparative Perspective. Ithaca, N.Y.: Cornell University Press.

Abdelal, R., Blyth, M., and Parsons, C. (2010) Constructing the International Economy. Ithaca, N.Y.: Cornell University Press

Ashizawa, K. (2008) When Identity Matters: State Identity, Regional Institution-Building, and Japanese Foreign Policy. International Studies Review, 10 (3), 571-598.

Aral, B. (2001) Dispensing with Tradition?: Turkish Politics and International Society During the Özal Decade, 1983-93. Middle Eastern Studies 37 (1), 72-88

Aslan, A. (2012) The Foreign Policy-Hegemony Nexus: Turkey's Search for a New Subjectivity in World Politics and Its Implications on US-Turkey Relations. Perceptions: Journal of International Affairs, 17(4), 159-184

Aslan, A. (2013) Problematizing Modernity in Turkish Foreign Policy: Identity, Sovereignty and Beyond. Uluslararası Hukuk ve Politika Dergisi, 9(33), 27-57

Baykal, D. (2006) "Baykal, Hükumetin Dış Politikasını Eleştirdi." Hürriyet, February 24, Accessed http://www.hurriyet.com.tr/gundem/3981567.asp.

Benhabib, S. (2004) The Rights of Others: Aliens, Residents, and Citizens. Cambridge University Press

Brubaker, R. and Cooper, F. Beyond 'Identity'. Theory and Society, 29, 1-47

Burchill, S. (2005) The National Interest in International Relations Theory. New York: Palgrave McMillan

Chafetz, G., Spirtas, M. and Frankel, B. (1998) Introduction: Tracing the Influence of Identity on Foreign Policy, Security Studies, 8, p. 7-22

Clunan, A. (2009) The Social Construction of Russia's Resurgence: Aspirations, Identity, and Security Interests. Baltimore: Johns Hopkins University Press

Davutoglu, A. (2001) Stratejik Derinlik. Istanbul: Kure Yayinlari

Davutoglu, A. (2010a) Sınırlar Duvar Değil, Kapı Olacak." Yeni şafak, January 11, 2010. Accessed February 22, 2015 . http://www.yenisafak.com.tr/politika/sinirlar-duvar-degil-kapi-olacak$11.01 .2010-234544$

Davutoglu, A. (2010b) Davutoglu: Middle East has a unique place in the redesign of the world," Zaman, March 4. Accessed http://www.zaman.com.tr/dunya_davutoglu-dunyanin-yeniden- 
sekillenmesinde-ortadogu-ayri-bir-yere-sahip_957876.html

Davutoglu, A. (2010c) "Sınır Istemiyoruz." Yeni Şafak, April 27. Accessed http://www.yenisafak.com.tr/politika/sinir-istemiyoruz-254312.

Davutoğlu, A. (2011) Dışişleri Bakanı Sn. Ahmet Davutoğlu'nun IV. Büyükelçiler Konferansı Açış Konuşması. Accessed https://www.mfa.gov.tr/disisleri-bakani-sn_-ahmet-davutoglu_nuniv_-buyukelciler-konferansi-acis-konusmasi_-23-aralik-2011.tr.mfa

Davutoğlu, A. (2012a) "Kaybettiğimiz Topraklarda Buluşacağız." Haberturk, January 21 , Accessed http://www.haberturk.com/gundem/haber/708252-kaybettigimiz-topraklarda-bulusacagiz.

Davutoglu (2012b) "Davutoğlu'ndan 10. Yıl Dersi," TimeTurk, June 7. Accessed http://www.timeturk.com/m/haber.asp?id=508890.

Davutoglu, A. (2013) FM Davutoğlu: Why Are We Referred to as Neo-Ottomans? Daily Sabah, March 4, Accessed http://www.dailysabah.com/politics/2013/03/04/fm-davutoglu-whyare-we-referred-to-as-neoottomans.

Davutoglu, A. (2015) Turkey's Zero-Problems Foreign Policy," Foreign Policy. May

Directorate of Public Diplomacy (2015) Official numbers from Prime Ministry Public Diplomacy Directorate. Accessed http://kdk.gov.tr/haber/yuksek-duzeyli-isbirligi-mekanizmalari/452

Erdogan, R. (2011) Türkiye Tarihi Okunmadan Ortadoğu'nun, Balkanlar'ın, Kafkasya'nın Tarihi Asla Ve Asla Yazılamaz." Zaman, February 26. Accessed http://www.zaman.com.tr/gundem_erdogan-turkiye-tarihi-okunmadan-ortadogununbalkanlarin-kafkasyanin-tarihi-asla-ve-asla-yazilamaz_1099744.html

Erdogan, R. (2012) "Erdogan 'ne isimiz var' Diyenlere Fena Ofkelendi." Yeniçă̆. March 21, Accessed: http://yg.yenicaggazetesi.com.tr/habergoster.php?haber $=65067$.

Ergin, S. (2012) "Erdoğan ve Tarih (2) Dış Politikada Ecdadı Sahiplenme Doktrini. Hurriyet, December 1 Accessed http://www.hurriyet.com.tr/yazarlar/22051883.asp.

Finnemore, M. (1996) National Interests in International Society. Ithaca, N.Y.: Cornell University Press

Hopf, T. (2009) Identity Relations and the Sino-Soviet Split in Abdelal, R. et al. (ed.) Measuring Identity: A Guide for Social Scientists. Cambridge: Cambridge University Press

Hopf, T. (2012) Reconstructing the Cold War: The Early Years, 1945-1958. Oxford: Oxford University Press.

Horowitz, M. (2002) Research Report on the Use of Identity Concepts in International Relations. Unpublished manuscript, Harvard Identity Project

IHA (2012) "Ben Derim De Sen Diyebilir Misin?" Ihlas Haber Ajansi, October 10, Accessed http://www.iha.com.tr/haber-ben-derim-de-sen-diyebilir-misin-246460/.

Jepperson, R., Wendt, A. and Katzenstein, P. (1996) Norms, Identity, and Culture in National Security. Peter Katzenstein (Ed.) in The Culture of National Security: Norms and Identity in World Politics, New York: Columbia University Press.

Kardas, S. (2009) Turkey's Bid to Raise Influence in Middle East. Strategic Comments, 16, 1-3.

Kılıçdaroğlu, K. (2010) Türkiye Ortadoğu Bataklığına çekiliyor. Sonsayfa Haberler, June 1, Accessed http://www.sonsayfa.com/Haberler/Siyaset/Turkiye-Ortadogu-batakliginacekiliyor-157121.html.

Kirisci, K. (2009) The Transformation of Turkish Foreign Policy: The Rise of the Trading State. 
New Perspectives on Turkey, 40, 29-57

Kubálková, V. (ed) (2001) Foreign Policy in a Constructed World. Armonk, N.Y.: M.E. Sharpe.

Mufti, M. (2002) From Swamp to Backyard: The Middle East in Turkish Foreign Policy in Friedman, R. (Ed.) The Middle East Enters the $21^{\text {st }}$ Century. Gainseville, Florida: University of Florida Press

Onuf, N. (1998) Constructivism: A User's Manual in Kubalkova, V. et al (Ed.) International Relations in a Constructed World. Armonk, N.Y.: M.E. Sharpe

Seabrooke, L. (2007) Varieties of Economic Constructivism in Political Economy: Uncertain Times Call for Disparate Measures. Review of International Political Economy, 14, 371-385.

Soysal, M. (2012) Secular Foreign Policy. Cumhuriyet Gazetesi, August 17. Accessed http://www.cumhuriyet.com.tr/?hn=359720.

Turgut, S. (2012) Türkiye Nasıl Büyük Abi Olur? Haberturk, November 26. Accessed http://www.haberturk.com/yazarlar/serdar-turgut-2025/797557-turkiye-nasil-buyuk-abiolur.

Türk, A. (2007) DTP: Operasyon Türkiye'yi Ortadoğu Bataklığına çeker." Radikal, October 17. Accessed http://www.radikal.com.tr/haber.php?haberno=235926.

Waltz, K. (1979) Theory of International Politics. Long Grove, Illinois: Addison-Wesley Pub.

Weldes, J. (1999) Constructing National Interests: The United States and the Cuban Missile Crisis. Minnesota: University of Minnesota Press

Wendt, A. (1992) Anarchy is What States Make of It: The Social Construction of Power Politics. International Organization, 46 (2), 391-425

Wendt, A. (1994) Collective Identity Formation and the International State. American Political Science Review, 88 (2), 384-396

Wendt, A. (1999) Social Theory of International Politics. Cambridge: Cambridge University Press.

Yeni Safak (2010) "Economic Integration Works." Yenisafak, June 4. Accessed http://yenisafak.com.tr/Politika/?t=04.06.2010\&i=26091 1 .

Zehfuss, M. (2002) Constructivism in International Relations: The Politics of Reality. Cambridge University Press 